\title{
Therapeutic potential of VIP vs PACAP in diabetes
}

\author{
Ahter D Sanlioglu ${ }^{1,2}$, Bahri Karacay ${ }^{4}$, Mustafa Kemal Balci ${ }^{1,3}$, Thomas S Griffith ${ }^{5}$ and \\ Salih Sanlioglu ${ }^{1,2}$ \\ ${ }^{1}$ Human Gene and Cell Therapy Center, Akdeniz University Hospitals and Clinics, B Block, 1st floor, Campus, Antalya 07058, Turkey \\ ${ }^{2}$ Department of Medical Biology and Genetics and ${ }^{3}$ Division of Endocrinology and Metabolism, Department of Internal Medicine, Faculty of Medicine, Akdeniz University, \\ Antalya 07058, Turkey \\ ${ }^{4}$ Division of Child Neurology, Department of Pediatrics, University of lowa, lowa City, lowa 52242, USA \\ ${ }^{5}$ Department of Urology, University of Minnesota, Minneapolis, Minnesota 55455, USA \\ (Correspondence should be addressed to S Sanlioglu at Human Gene and Cell Therapy Center, Akdeniz University Hospitals and Clinics; Email: sanlioglu@akdeniz.edu.tr)
}

\begin{abstract}
Type 2 diabetes (T2D) is characterized by chronic insulin resistance and a progressive decline in beta-cell function. Although rigorous glucose control can reduce morbidity and mortality associated with diabetes, achieving optimal longterm glycemic control remains to be accomplished in many diabetic patients. As beta-cell mass and function inevitably decline in T2D, exogenous insulin administration is almost unavoidable as a final outcome despite the use of oral antihyperglycemic agents in many diabetic patients. Pancreatic islet cell death, but not the defect in new islet formation or beta-cell replication, has been blamed for the decrease in beta-cell mass observed in T2D patients. Thus, therapeutic approaches designed to protect islet cells from apoptosis could significantly improve the management of T2D, because of its potential to reverse diabetes not just ameliorate glycemia. Therefore, an ideal beta-cell-preserving agent is expected to protect beta cells from apoptosis and stimulate postprandial insulin secretion along with increasing beta-cell replication and/or islet neogenesis. One such potential agent, the islet endocrine neuropeptide vasoactive intestinal peptide (VIP) strongly stimulates postprandial insulin secretion. Because of its broad spectrum of biological functions such as acting as a potent anti-inflammatory factor through suppression of Th1 immune response, and induction of immune tolerance via regulatory T cells, VIP has emerged as a promising therapeutic agent for the treatment of many autoimmune diseases including diabetes.
\end{abstract}

Journal of Molecular Endocrinology (2012) 49, R157-R167

\section{Obesity and inflammation}

Diabetes is the third most common disease and fourth leading cause of death in the world (Tabak et al. 2012). Insulin resistance, impaired glucose tolerance, and excessive glucagon secretion are the prominent features of type 2 diabetes (T2D; Knop et al. 2009). As improper environmental factors (i.e. sedentary lifestyle and unhealthy eating habits) increase the frequency of T2D, failure to develop effective treatments also contributes to the widespread prevalence of diabetes. Metabolic imbalance between food intake (excessive eating) and energy expenditure (loss of physical activity) contributes to the accumulation of toxic metabolites (diacyl glycerol and ceramide) in liver and muscle triggering insulin resistance. The buildup of toxic metabolites increases internal fat deposition, which serves as a main source of inflammation ultimately predisposing individuals to a variety of diseases including diabetes. Although inflammation is not always responsible for altered insulin sensitivity, it has long been suspected that chronic inflammatory signals may eventually produce insulin resistance. It is still a matter of debate, however, whether the inflammation associated with obesity is a cause or an effect in induction of insulin resistance. Nonetheless, obesity is characterized by the chronic low-level state of inflammation. Accordingly, pancreatic beta cells eventually fail and die because of the tremendous stress associated with the need for excessive insulin production.

\section{Insulin resistance, glucose intolerance, and islet cell loss}

Insulin resistance, a major risk factor for cardiovascular diseases (Niswender 2010), is manifested by the inability of glucose to enter into peripheral tissues 
leading to hyperglycemia. As long-lasting hyperglycemia is toxic to vital organs including the heart, blood vessels, eyes, kidneys, and nerves, the mortality rate of diabetics is five times greater than that of nondiabetics. Insulin resistance combined with environmental and/or genetic factors can cause pancreatic beta-cell failure. Genetic modifications, as a result of improper environmental factors, were initially held responsible for insulin resistance phenotype observed in T2D-susceptible individuals. Genome-wide association studies (GWAS) were recently conducted in T2D patients, revealing T2D-associated small nucleotide polymorphisms (SNPs) located on 24 different genetic loci (Stolerman \& Florez 2009). In these studies, the T2D-related SNP profile was mostly related to insulin secretion pathways rather than insulin sensitivity. As single-marker GWAS may generally overlook the potential interaction of multiple genes responsible for the development of disease phenotype, pathway-based GWAS analysis was conducted to identify genes/variants and relevant biological pathways predisposing individuals to complex diseases such as diabetes (Liu et al. 2010). Analysis of the data generated from 1000 US citizens involving screening of 500000 SNPs demonstrated that the vasoactive intestinal peptide (VIP) pathway was significantly associated with both BMI and fat mass, suggesting the importance of the VIP pathway in the development of obesity.

During the development of T2D, glucose tolerance is generally lost long before the actual appearance of disease. Insulin resistance accompanied by a functional loss of beta cells leads to hyperglycemia in newly diagnosed T2D patients, as revealed by a $50 \%$ decrease in pancreatic beta-cell function and $40 \%$ loss in islet cell mass. The fact that no hyperglycemia has been reported without the functional loss of beta cells supports this notion. An intense insulin regimen can delay functional deterioration of pancreatic beta cells in newly diagnosed T2D patients, but it cannot entirely prevent it from happening. Consequently, glycemic control can be lost despite the use of antiglycemic medications. Endoplasmic reticulum stress induced by an intense demand for insulin production has been considered as the main cause of functional loss of beta cells ultimately crippling beta-cell function (Leibowitz et al. 2011). In this scenario, glucose toxicity acting together with saturated fatty acids, lipoproteins, and proinflammatory cytokines induces inflammation in the pancreas leading to apoptotic beta-cell destruction.

Weight loss or insulin-sensitizing agents cannot simply cure obese diabetics, because insulin-resistant obese individuals may develop a compensatory mechanism of boosting insulin secretion via increasing beta-cell mass and stay healthy without developing diabetes for years. Nevertheless, diabetic patients (regardless of being obese or lean) possess less beta-cell mass compared with healthy individuals due to eventual destruction of pancreatic beta cells. T2D only becomes evident when beta-cell mass can no longer compensate for physiological insulin need. An increase in beta-cell apoptosis, but not a decrease in beta-cell replication or new islet formation, has been blamed for the loss of beta-cell mass observed in T2D patients (Butler et al. 2003). In this scenario, antigens from apoptotic beta cells stimulate autoreactive T cells leading to the autoimmune destruction of pancreatic beta cells both in T2D and in T1D. Medical intervention may be useful in recovering beta-cell function or restoring beta-cell mass, but only during early stages of T2D. Because the decrease in beta-cell mass is considered to be one of the most important defects in T2D patients, antiapoptotic strategies are very crucial in protecting pancreatic islets from destruction. While the potential need for an anti-inflammatory medication is appreciated, both targeted and efficacious anti-inflammatory drugs are yet to be developed for the treatment of T2D. As impaired insulin secretion is the primary defect in diabetics, agents that stimulate glucoseinduced insulin secretion (insulinotropic agents) while protecting cells from apoptosis represent a novel class of medications for the treatment of diabetes. We will focus this review on the antidiabetic potential of pituitary adenylate cyclase-activating polypeptide (PACAP) and VIP - two agents with antiapoptotic and insulinotropic effects that can augment insulin release from pancreatic beta cells (Vaudry et al. 2009, Moody et al. 2011).

\section{Basic mechanism of glucose-induced insulin secretion}

Pancreatic beta cells (islets of Langerhans) are mainly responsible for controlling blood glucose levels through insulin secretion. Insufficient release of insulin from pancreatic islets results in glucose toxicity leading to T2D (Ahren \& Pacini 2005). Glucose is the most potent stimulator of insulin secretion, but the amount of insulin released from pancreatic beta cells is determined by both extracellular and intracellular signaling including nutritional, neuronal, and hormonal factors. Glucose breakdown in beta cells increases ATP/ADP ratio, then closes $\mathrm{K}_{\mathrm{ATP}}$ channels. Membrane depolarization followed by $\mathrm{Ca}^{2+}$ influx into the cell results in insulin secretion (Henquin 2009). In addition to glucose, gastrointestinal hormones, amino acids, fatty acids, and neurotransmitters can modulate glucose-induced insulin secretion via cAMP-mediated pathways (Henquin 2000). Insulin secretion is naturally increased following meals, a physiological phenomenon known as postprandial insulin secretion. This process involves the combined action of glucose, 
gastrointestinal hormones, and neurotransmitters released from autonomic nerves. Acetylcholine released as a result of vagal nerve activation triggers insulin secretion during the early phase of meal ingestion (Ahren 2000). Thus, there is a sudden increase in plasma insulin levels right before digestion of the meal even before blood glucose excursion (Ahren \& Holst 2001). Apart from acetylcholine, there are other neurotransmitters that stimulate insulin secretion via vagal nerve activation.

VIP is a single 28-amino acid peptide hormone involved in the regulation of the secretory function of the endocrine pancreas. PACAP, sharing $68 \%$ amino acid sequence identity to VIP, exists in two amidated forms known as PACAP38 and PACAP27. VIP expression is exclusively limited to parasympathetic neurons, whereas PACAP expression is localized to postganglionic parasympathetic, sympathetic, and sensory neurons in the pancreas. Nonetheless, PACAP and VIP are both released from the pancreas upon parasympathetic nerve activation (Hannibal \& Fahrenkrug 2000). The fact that VIP and PACAP expressions are also localized to pancreatic islets suggested that PACAP and VIP could function both as neurotransmitters released from islet neurons and as endocrine peptides secreted from pancreatic islets (Yada et al. 1997). Owing to pleiotropic effects of these neurotransmitters on islet cell mass and function, numerous studies have explored the antidiabetic potential of VIP and PACAP including their potential to modulate glucose-induced insulin secretion (Nakata et al. 2010, Sakurai et al. 2011).

\section{PACAP/VIP-modified glucose-induced insulin secretion}

PACAP- and VIP-induced signalings are carried out by two VIP-shared type 2 receptors (VIP/PACAP receptor 1 (VPAC1) and VPAC2, and one PACAPspecific type 1 (PAC1) receptor; Fig. 1; Harmar et al. 2012). In situ hybridization studies of pancreatic islets demonstrated the presence of both PAC1 and VPAC2 expressions in islets, but not VPAC1 (Inagaki et al. 1994, Kulkarni et al. 1995). PAC1, VPAC1, and VPAC2 expressions were confirmed in pancreatic beta cells only after using very sensitive RT-PCR methods (Borboni et al. 1999). These three receptors belong to the $G$ protein-coupled receptor family and activate adenylate cyclase (AC) through $\mathrm{G}$ proteins (Ahren 2009). As a result of AC activation, cAMP is produced from ATP and acts as a second messenger for both PACAP- and VIP-mediated signaling. The increase in cAMP production also stimulates protein kinase A (PKA) and/or cAMP exchange factor of EPAC family, closing $\mathrm{K}_{\text {ATP }}$ channels and leading to $\mathrm{Ca}^{2+}$ influx into cells, and finally inducing insulin secretion from

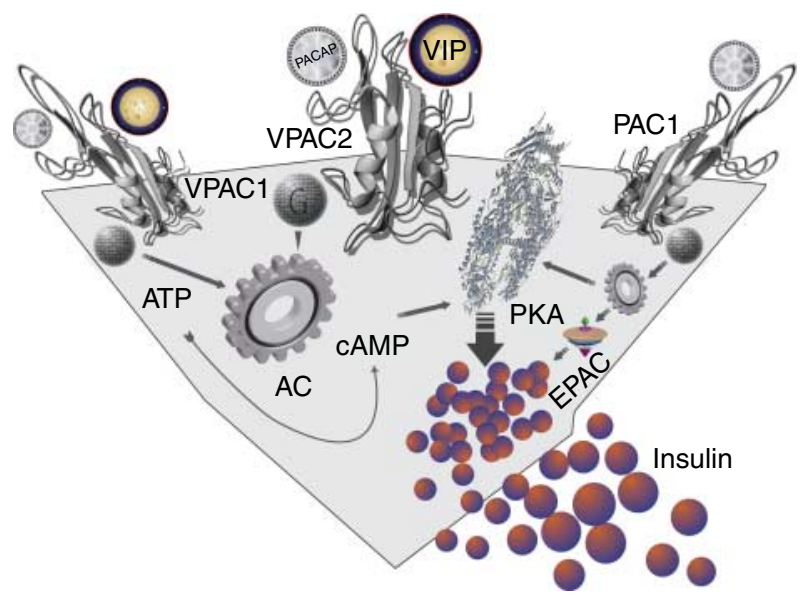

Figure 1 Mechanism of VIP-augmented glucose-induced insulin secretion. While VPAC1 and VPAC2 receptors can be activated by both VIP and PACAP, PAC1 can only selectively interact with PACAP. G protein-coupled receptors stimulate $G$ proteins resulting in the activation of $A C$, a cAMP-producing enzyme from ATP. Binding of cAMP to PKA results in dissociation of catalytic subunits of PKA from regulatory subunits phosphorylating several cytoplasmic proteins involved in exocytosis of insulin. However, VIP-induced insulin secretion takes place only in the presence of glucose. VIP and PACAP have insulinotropic effects on pancreatic beta cells. Full colour version of this figure available via http://dx. doi.org/10.1530/JME-12-0156.

secretory vesicles (Eliasson et al. 2003). PACAP is the most potent insulinotropic peptide presently known, because it induces insulin secretion even at subpicomolar concentrations $\left(10^{-13} \mathrm{M}\right)$. By comparison, PACAP and VIP concentrations between the range of $10^{-11}$ and $10^{-8} \mathrm{M}$ are equipotent in stimulating glucose-induced insulin secretion from beta cells (Bertrand et al. 1996). Interestingly, VIP- and/or PACAP-induced $\mathrm{Ca}^{2+}$ increase can only take place in the presence of glucose. While glucose initiates insulin secretion, VIP and PACAP amplify glucose-induced insulin secretion pathways. For example, an increase in the ATP/ADP ratio as a result of glucose breakdown activates L-type calcium channels via membrane depolarization, which is induced by the closing of $\mathrm{K}_{\mathrm{ATP}}$ channels. Further increase in the cytoplasmic concentration of calcium can be achieved either with activation of PKA and/or opening of nonselective cation channels, both of which are activated by VIP and PACAP signaling (Ahren 2008).

To determine the extent to which age or metabolic status influence insulin response of pancreatic islets to PACAP and VIP, the insulin response has been investigated in obese vs lean, young vs aged mice (Persson-Sjogren et al. 2006). Intriguingly, VIP and PACAP induced strong insulin secretion from islets isolated from young and obese mice, while islets isolated from lean mice exhibited only a modest effect. As islets isolated from the aged mice, regardless of 
being lean or obese, displayed less sensitivity toward these neuropeptides, both age and metabolic status have to be taken into account when considering optimum insulin secretion induced by PACAP and VIP. Thus, deregulated PACAP and VIP signaling might be responsible for the reduced glucose-induced insulin secretion observed in patients with T2D and/or elderly individuals.

PAC1 activates phospholipase C (PLC) in some tissues (Spengler et al. 1993), but the extent to which PACAP can activate PLC signaling has yet to be proven as enhanced inositol phosphate production has not been observed in pancreatic islets (Jamen et al. 2002). The fact that intracellular $\mathrm{Ca}^{2+}$ concentrations increase in isolated pancreatic alpha cells (just like in beta cells), leading to glucagon secretion following PACAP stimulation, demonstrates that similar signal transduction pathways are in place in both pancreatic cell types.

\section{Use of genetically modified mouse models to determine islet-related functional roles of PACAP and VIP}

To reveal functional roles of PACAP and VIP on pancreatic islets, $\mathrm{PACAP}^{-/-}$mice (Hashimoto et al. 2001), VIP $^{-/-}$mice (Martin et al. 2010), and transgenic mice overexpressing PACAP (Yamamoto et al. 2003) or VIP (Kato et al. 1996) specifically in beta cells have been generated. Hyperactivity, reduced fertility, increased mortality, and altered brain functions were detected in PACAP ${ }^{-}$- mice (Shintani et al. 2003). Although reduced insulin secretion was detected following i.p. glucose injections in $\mathrm{PACAP}^{-/-}$mice, no change in glucose tolerance was evident. Interestingly, both glucose tolerance and insulin sensitivity were altered in diabetic obese mice upon injection with PACAP receptor antagonist (Green et al. 2006). Despite having elevated plasma glucose, insulin, and leptin levels, there was no alteration in islet cell mass in $\mathrm{VIP}^{-/-}$mice (Martin et al. 2010). The lack of alteration in islet cell mass (including subtle phenotypic variations) in $\mathrm{VIP}^{-/-}$mice was attributed to the presence of some compensatory mechanisms indulging PACAPinduced activation of VPAC1 and/or VPAC2 receptors that may potentially substitute for VIP activity in $\mathrm{VIP}^{-/-}$mice. While a diabetic-like state was evident in the VIP ${ }^{-/-}$mice, a series of physiological alterations such as reduced leptin receptor activity and increased glucagon-like peptide 1 (GLP1) expression in the tongue occurred in knockout animals as means to ameliorate diabetic-like pathology. Additional studies with VIP/PHI-deficient mice showed the inability of these mice to follow a coherent circadian rhythm
(Colwell et al. 2003) and moderate pulmonary arterial hypertension (PAH; Said et al. 2007).

PACAP has been primarily evaluated as an insulin secretagogue in numerous studies, but transgenic expression of PACAP revealed additional information about its proliferative effect on islet cell mass. Transgenic mice overexpressing PACAP in pancreatic beta cells displayed elevated insulin secretion after oral glucose loading, but no change in plasma glucose and glucagon levels was reported (Yamamoto et al. 2003). In addition to attenuating streptozotocin (STZ)-induced hyperglycemia, morphometric analysis revealed increased beta-cell mass in PACAP-transgenic mice, suggesting an essential role for PACAP in islet cell proliferation and differentiation. Intriguingly, PACAP has opposing mitogenic effects depending on target cell type (Sherwood et al. 2000). For example, PAC1 activation may result in either the activation of peripheral sympathetic neuroblasts or inhibition of cerebral cortical precursors (Lu et al. 1998). The differences in PACAP action are mainly attributed to the presence of alternative splice variants of PAC1 receptor resulting in the activation of divergent signaling pathways (Meyer 2006). PACAP in the CNS plays very important roles in neuroprotection of the adult brain through inhibition of the MAPK family (JNK/SAPK and P38). PACAP can also induce astrocyte differentiation by stimulating IL6 secretion during development (Shioda et al. 2006). Despite the coronary vasodilatative effects of PACAP and VIP, VIP possesses antiproliferative effects both on vascular (Hultgardh-Nilsson et al. 1988) and airway (Maruno et al. 1995) smooth muscle cells. The fact that VIP ${ }^{-/-}$ mice displayed PAH supports this observation (Said et al. 2007).

Transgenic mice overexpressing VIP in pancreatic beta cells manifested reduced plasma glucose levels (Kato et al. 1994), but more importantly VIP expression in beta cells ameliorated glucose intolerance in $70 \%$ of depancreatized mice. These data suggest that VIP secreted from the transgenic beta cells effectively augmented glucose-induced insulin secretion (Fig. 2) . VIP and PACAP have similar functions in beta cells, but the differences in glucose tolerance suggest that these neuroendocrine hormones have different roles on peripheral tissues. For example, adrenalin-induced hepatic glucose production occurred after PACAP administration but not after VIP administration (Yokota et al. 1995). Despite the ability of VIP to augment glucose-induced insulin secretion, it has yet to be determined to what extent VIP overexpression in pancreatic beta cells influences islet cell mass (Fig. 2).

Examining PACAP or VIP receptor knockout mice is another way of assessing functional roles of PACAP and VIP on pancreatic islets. PAC1 ${ }^{-/-}$mice displayed $50 \%$ decrease in PACAP-mediated glucose-induced 


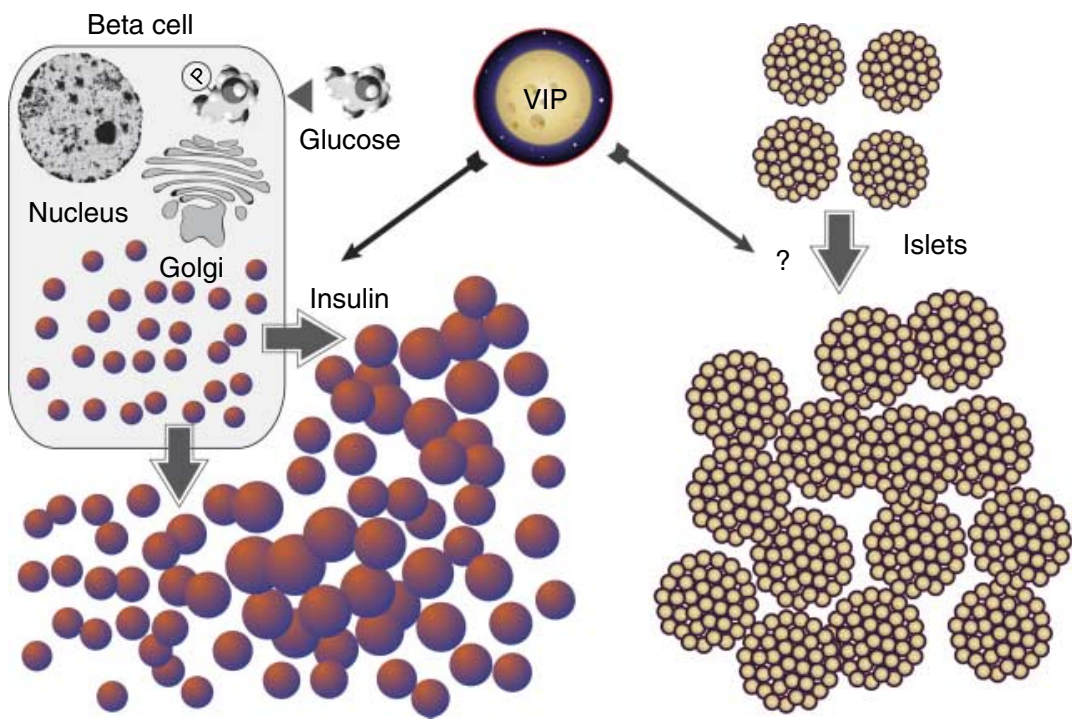

Figure 2 Potential functional roles of VIP on pancreatic beta cells. VIP treatment augments glucose-induced insulin secretion lowering blood glucose of diabetics. Although ectopic PACAP expression has been shown to enhance proliferation of pancreatic beta cells in STZ-induced diabetes, whether or not VIP overexpression in pancreatic beta cells would result in a similar phenotype has not been tested yet. Full colour version of this figure available via http://dx.doi.org/10.1530/JME-12-0156.

insulin secretion without any change in basal insulin or plasma glucose levels (Jamen et al. 2000). Glucoseinduced insulin secretion was also reduced in $\mathrm{PAC1}^{-/-}$ mice as revealed by oral and i.v. glucose administration. Consequently, PAC1 receptors are needed not only for PACAP-mediated insulin secretion but also for glucoseinduced insulin secretion, suggesting that effective glucose-induced insulin secretion requires PACAP signaling pathways just like with GLP1 (Vilsboll \& Holst 2004). The fact that glucose-induced insulin secretion is decreased from freshly isolated islets when PACAP neutralizing antibodies are added confirmed that PACAP is an autocrine and/or paracrine acting islet neuropeptide necessary for optimal glucoseinduced insulin secretion (Yada et al. 1997, Filipsson et al. 1999). In addition, reduced glucagon response was reported in insulin-mediated experimentally induced hypoglycemia in $\mathrm{PAC1}^{-/-}$mice (Persson \& Ahren 2002). Thus, PACAP-stimulated PAC1 receptor activation mediates glucagon response to insulin-induced hypoglycemia.

Assessments of VIP receptor knockout mice revealed improved lean mass but decreased fat mass associated with a reduction in body weight in $\mathrm{VPAC}^{-/-}$mice (Asnicar et al. 2002). Although glucose-induced insulin secretion was decreased, no alteration on glucose tolerance was reported in oral glucose tolerance tests performed in VPAC2 ${ }^{-/-}$mice. Moreover, the fact that glucose is cleared faster from the blood upon insulin injection suggests that the VPAC2 knockout phenotype increased insulin sensitivity. These results demonstrate that VPAC2 receptors are also needed for optimum insulin release from pancreatic islets as well.

VPAC1-null mutant mice have recently been generated resulting in fetal, neonatal, and postnatal death due to growth retardation, intestinal obstructions, and hypoglycemia (Fabricius et al. 2011). Intriguingly, VPAC1 knockout mice manifested lower baseline blood glucose levels compared with wild-type littermates. Oral glucose challenge demonstrated rapid hypoglycemia and a failure to restore blood glucose to normal levels by $2 \mathrm{~h}$. These results demonstrated that VPAC1 is required for both embryonic/neonatal development and proper function of endocrine pancreas.

\section{Insulinotropic agents for the treatment of diabetes}

Restoring plasma glucose to prediabetic levels can reduce microvascular and neurological complications of diabetes. However, current antidiabetic drugs such as sulphonylurea, metphormin, and insulin provide limited long-term glycemic control due to the progressive nature of diabetes (Peterson 2012). By comparison, incretin-based therapeutics have the potential to restore beta-cell function and reverse islet cell loss observed in T2D (Aroda et al. 2012, Vilsboll et al. 2012). As demonstrated in experimental animal models, GLP1 is one of the most potent insulinotropic peptides having a significant impact on beta-cell mass 
(Ahren et al. 2003). Just like VIP and PACAP, GLP1 belongs to the secretin family of proteins and is currently in clinical use for the treatment of patients with T2D (Dejager \& Schweizer 2012). GLP1 is naturally released from the gut into circulation after a meal. Because natural peptide forms of GLP1 and glucosedependent insulinotropic peptide (GIP; incretins) are quickly destroyed by dipeptidyl peptidases 4 (DPP4), these intestinal hormones currently have limited clinical utility (Vilsboll 2009). As a result, DPP4-resistant GLP1 receptor agonists (Exendin 4; exanatide) and DPP inhibitors that increase the stability of endogenous incretin hormones were developed (Aroda et al. 2012). DDP4 inhibitors were recently recommended by the American Diabetes Association (ADA) and the European Association for the Study of Diabetes (EASD) as an add-on therapy to metphormin, especially when patients are intolerant of or have contraindications to sulfonylurea and insulin. However, gastrointestinal side effects $(45 \%$ of the diabetic patients using exanatide) and pancreatitis risk observed in some patients impose a restriction in clinical use of exanatide as a therapeutic agent, prompting scientists to explore safer and more effective new alternatives to antidiabetic agents.

\section{Glucagon receptor antagonists and VPAC2 selective agonists for T2D}

Because VIP and PACAP are insulinotropic peptides, activation of PAC1 or VPAC2 receptors potentially represents a novel treatment modality for T2D in terms of insulin secretion. For example, daily PACAP injection in high-fat diet-induced obesity or GotoKakizaki rats enhanced glucose tolerance and reduced circulating glucose levels (Yada et al. 2000). However, PACAP-mediated epinephrine secretion and plasma glucagon levels may worsen prognosis of T2D instead of improving it. More importantly, PACAP-induced severe vasodilatation (hypotension) precludes its future utility as a therapeutic agent for T2D (Zhu et al. 2003). VIPmediated glucagon secretion has also been reported by previous studies (Ahren 1991). Interestingly, both VIP and PACAP stimulated glucagon secretion from pancreas perfused with only $2.8 \mathrm{mM}$ glucose but not with $8.3 \mathrm{mM}$ of glucose. It is well established that VIP is released from the pancreas during vagal nerve stimulation. Parasympathetic nerve activation induced by hypoglycemia results in VIP release from pancreas stimulating glucagon secretion to maintain euglycemia. Thus, VIP-induced glucagon secretion has been suggested to be a mechanism to counterbalance insulininduced hypoglycemia (Havel et al. 1997). In accordance with this observation, experimental and clinical studies employing VIP have not been associated with any concerns regarding its potential effect on glucagon levels. Nevertheless, because constant hyperglucagonemia is the main contributor to hyperglycemia (Reaven et al. 1987), blocking glucagon signaling was tested as a therapeutic strategy for T2D (Sloop et al. 2005). By this token, injection of a glucagon receptor antagonist developed for high-fat diet-induced insulin resistance decreased hyperglycemia and augmented islet function improving insulin sensitivity (Winzell et al. 2007).

On the other hand, VPAC2 receptors are highly expressed on pancreatic islets and they are not involved in glycogen breakdown in the liver. Therefore, the extent to which VPAC2 selective agonists enhance insulin secretion and facilitate glucose tolerance without stimulating hepatic glucose production has been investigated. VPAC2 selective agonists were very effective in augmenting insulin secretion without causing hypoglycemia (Tsutsumi et al. 2002). However, as the first generation of VPAC2 selective agonists manifested stability problems in vivo, new DPP4-resistant VPAC2 analogs were generated (Pan et al. 2007) and studies are underway to determine the efficacy of these new therapeutic compounds. Because VPAC2 selective agonists are considered to be new therapeutic agents for the treatment of T2D, and VIP is the natural ligand for VPAC2, VIP-mediated gene transfer strategies also represent an experimental treatment modality for diabetes.

\section{VIP-mediated gene transfer studies}

T1D, also known as insulin-dependent diabetes mellitus, is a metabolic disease caused by autoimmune destruction of pancreatic beta cells secreting insulin (Dirice et al. 2009). Natural immune cells and Th1 cytokines (Sanlioglu et al. 2008b) play key roles in the generation of inflammation causing pancreatic tissue damage during the early phase of T1D (Sanlioglu et al. 2008a). As VIP can skew the proinflammatory cytokine profile to an anti-inflammatory response, the extent to which VIP has any therapeutic effect on autoimmune model of diabetes has been tested. VIP injection prevented the development of T1D in non-obese diabetic (NOD) mice (Rosignoli et al. 2006). Protection from diabetes was attributed to regulatory $\mathrm{T}$ cell activation, suppression of Th1 cytokines, and increased synthesis of IL10. As diabetes naturally develops in NOD mice, the process can be enhanced and synchronized using cyclophosphamide (CYD), a drug that disrupts the Th1/Th2 balance favoring Th1 type response (Dirice et al. 2011). Transfer of plasmid DNA encoding VIP also reduced the incidence of diabetes in CYD-injected NOD mice (Herrera et al. 2006), where the observed therapeutic effect was ascribed to the immune regulatory function of VIP modifying the 
cytokine profile from Th1 to Th2. VIP-mediated gene transfer studies are not only limited to autoimmune diabetes but also include other autoimmune diseases, as explained below.

NOD mice exhibit decreased salivary gland function and lymphocytic infiltration on exocrine glands, similar to what is seen in humans with Sjogren's syndrome (Kok et al. 2003). Administration of $\mathrm{rAAV}-2$ vector encoding human VIP gene into submandibular glands of NOD mice resulted in immunosuppression of the Sjogren's phenotype improving salivary gland flow (Lodde $e t$ al. 2006). Rheumatoid arthritis (RA) is another inflammatory disease characterized by uncontrollable proliferation of synovial cells (Bisgin et al. 2010). Experimental gene therapy modalities are being developed to facilitate the death of apoptosis-resistant synovial cells in RA (Terzioglu et al. 2007). TNF $\alpha$ inhibitors have the potential for serious side effects due to systemic immunosuppression, so the anti-inflammatory properties of VIP have been explored in an experimental model of collagen-induced arthritis (CIA). Delivery of VIP resulted in a therapeutic benefit in CIA involving $\mathrm{CD} 4{ }^{+} \mathrm{CD} 25^{+}$regulatory $\mathrm{T}$ cells (Gonzalez-Rey et al. 2006). Likewise, intraperitoneal delivery of lentiviral vectors encoding VIP (LentiVIP), generated an antiinflammatory response inducing $\mathrm{CD} 4{ }^{+} \mathrm{CD} 25^{+} \mathrm{FoxP}^{+}$ regulatory $\mathrm{T}$ cell activation characterized by an increase in IL10 and TGF $\beta$ synthesis within lymph nodes and joints (Delgado et al. 2008). Lastly, the argument of VIP as a potential therapeutic agent has been revealed in patients with PAH (St Hilaire et al. 2009), where there is insufficient VIP expression detected in serum and lung

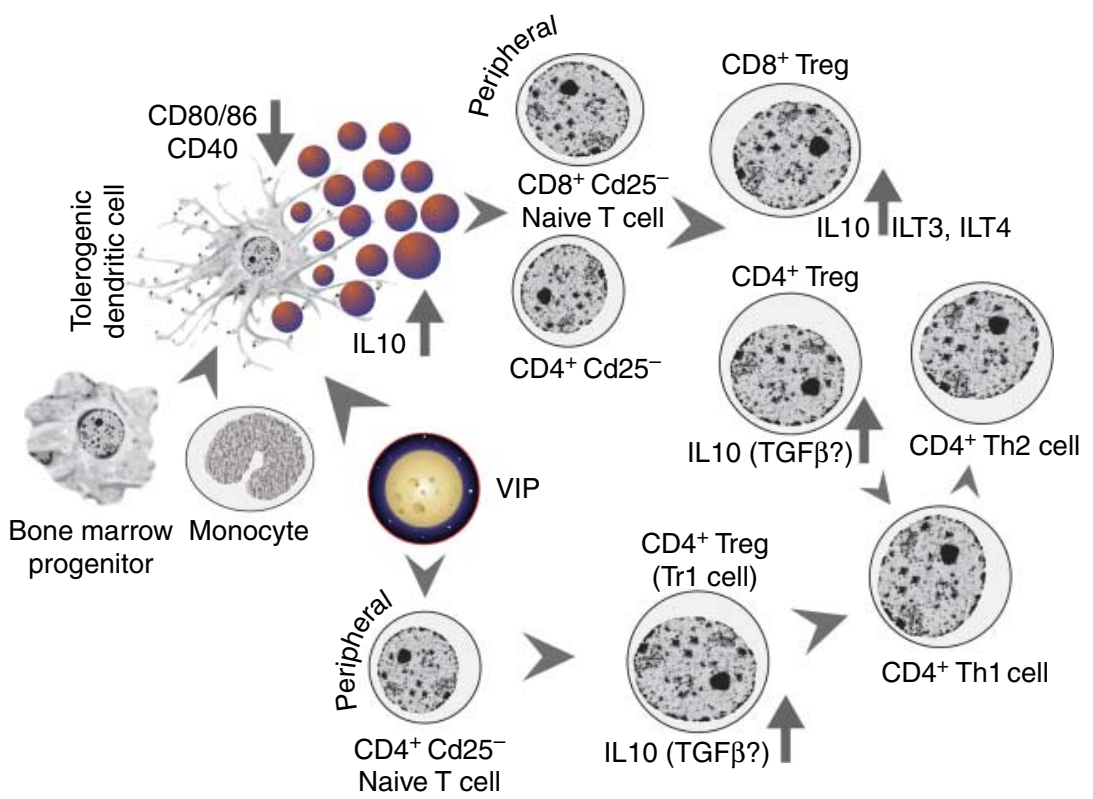

Figure 3 VIP-induced immune tolerance. VIP has two different ways of generating regulatory $T$ cells (Tregs) that are crucial for the maintenance of immune tolerance. Under the influence of VIP, monocytes and dendritic cells originating from bone marrow yield immature dendritic cells (DCs) characterized by low-level co-stimulatory molecule expression, such as CD40, CD80, and/or CD86. These immature DCs also display enhanced expression of IL10 (shown as spherical substances in figure) while TNF $\alpha$, IL12, and IL6 expressions are reduced. These tolerogenic dendritic cells (tDC) induce generation of $\mathrm{CD}^{+}{ }^{+}$and $\mathrm{CD} 8^{+} \mathrm{T}$ regulatory 1 (Tr1)-like cells from the peripheral $\mathrm{CD} 4^{+}$ and $\mathrm{CD} 8^{+}$but $\mathrm{CD} 25^{-}$naive T cells. The cytokine profile of the resulting Treg includes high levels of IL10/TGF $\beta 1$ and cytotoxic T-lymphocyte-associated antigen 4 (CTLA4) production, but little or no interferon $\alpha$ (INF $\alpha$ ), IL2, and IL4. CD8 ${ }^{+}$Tregs can also stimulate the expression of the immunoglobulin-like transcripts (ILT3 and ILT4) in antigenpresenting cells (APCs) thereby disrupting the antigen presentation process. Alternatively, VIP can generate $\mathrm{CD} 4^{+} \mathrm{CD} 25^{+} \mathrm{FoxP} 3^{+}$cells directly from the peripheral naive $\mathrm{CD} 4^{+} \mathrm{CD} 25^{-} \mathrm{T}$ cells. These cells express high levels of CTLA4 and produce substantial levels of IL10/TGF $\beta$. VIP-induced Tregs can block autoreactive Th1 cells to prevent autoimmunity favoring Th2 type response. Arrows in the figure indicate a decrease or an increase in the expression levels of molecules of interest while arrowheads show the direction of cell differentiation process. Full colour version of this figure available via http://dx.doi.org/10.1530/JME-12-0156. 
tissue (Petkov et al. 2003). All these results suggest that VIP-mediated gene therapy is a viable strategy against autoimmune diseases including autoimmune diabetes.

\section{Current status of VIP-mediated therapy and future scenarios for diabetes treatment}

All patients with T1D and most patients with T2D become insulin dependent due to the progressive nature of the disease, eventually leading to beta-cell loss (Sanlioglu et al. 2012). The increase in apoptosis, but not the decrease in new islet formation or beta-cell replication, is blamed for the loss of beta-cell mass observed in patients with T2D (Butler et al. 2003). Thus, therapeutic approaches that either interfere with apoptosis of beta cells and/or increase beta-cell mass have the potential not only for managing hyperglycemia but also for reversing disease progression (Peters 2010).

VIP is a neuropeptide of the secretin family just like GLP1 and PACAP with equipotent insulinotropic effects. More importantly, it is an effective antiinflammatory agent involved in suppression of Th1 immune response and activation of regulatory $\mathrm{T}$ cells for inducing immune tolerance (Fig. 3). For this reason, VIP is now considered to be an emerging therapeutic agent for autoimmune diseases such as RA, ulcerative colitis, multiple sclerosis, uveoretinitis, and T1D. Consequently, therapeutic efficacy of VIP has been tested in clinical trials of obstructive pulmonary disease, pulmonary hypertension, sepsis, and migraine (ClinicalTrials.gov identifiers: NCT00272896, NCT00464932, NCT00004494, and NCT00255320). These clinical trials demonstrated that VIP is well tolerated and manifested only minor side effects in treated patients.

Despite all these advantages, VIP is extremely sensitive to peptidases (DPP4) present in most tissues. Thus, multiple injections of VIP at high doses are required to observe any therapeutic effect. DPP4 degradation of VIP and PACAP has drastic consequences in the clinical utility of these neuropeptides. DPP4 is a cell surface serine dipeptidase involved in the regulation of the functional activities of many natural peptides including GLP1, GIP, VIP, and PACAP (Zhu et al. 2003). This ubiquitous N-terminal dipeptidase functions to liberate dipeptides (Xaa-Pro or Xaa-Ala) from the N-terminus of regulatory peptides (Mentlein 1999). Because the amino terminal domains of VIP and PACAP are crucial for the activation of their cognitive receptors, cleavage of these peptides by DPP4 blocks their agonistic activity (Lambeir et al. 2001). Furthermore, the N-terminally truncated peptides generated by DPP-4 function as antagonists (Robberecht et al. 1992).

Contrary to using peptide forms of therapeutic agents, some gene therapy vectors can provide longterm and stable gene expression. Thus, viral and nonviral VIP gene delivery methods have been under development (Lodde et al. 2004, Herrera et al. 2006). Despite the successful results obtained from these studies, especially against autoimmune diseases, some limitations of using gene therapy vectors were revealed in recent studies. For example, the clinical efficacy of plasmid DNA transfer is low. Adenoviral vectors only provide transient gene expression due to the antigenic character of adenoviral epitopes (Doerschug et al. 2002). AAV has limited cargo capacity and low transduction efficiency (Sanlioglu et al. 2001). Compared with other gene therapy vectors, lentiviral vectors appear to be the vector of choice when considering long-term gene expression, transduction efficacy, and safety (Elsner et al. 2012). As thirdgeneration lentiviral vectors can inactivate themselves following integration into the genome, they do not possess the insertional mutagenesis risk associated with retroviral vectors inducing oncogene activation. However, the efficacy of lentivirus-mediated VIP delivery remains to be tested in experimental animal model of diabetes. Thus, gene therapy approaches can be employed to generate functional VIP rather than VIP precursors having little or no biological activity.

To give an example of such a scenario, a high-fat diet/low-dose STZ diabetic animal model (Srinivasan et al. 2005) can be used to test the therapeutic efficacy of lentivirus-mediated VIP gene delivery against T2D. In this model, insulin resistance is generated via feeding animals with diets enriched in fat (Winzell \& Ahren 2004), and hyperglycemia is induced by STZ injection. Because of induction of insulin resistance and obesity, high-fat diet/low-dose STZ-treated rodents simulate natural disease progression and metabolic characteristics typical of individuals at increased risk for developing T2D. Consequently, the high-fat diet/ low-dose STZ model would be very valuable in testing of the therapeutic efficacy of lentivirus-mediated isletrestricted VIP gene expression. Properties of VIP relevant to T2D therapy may include but are not limited to insulinotropic action to avoid glucose intolerance (Fig. 2), anti-inflammatory properties to avert apoptosis (Fig. 3), and stimulation of islet cell proliferation/ differentiation (?) to compensate beta-cell loss (Fig. 2).

In conclusion, despite the presence of numerous novel therapeutic agents developed against $\mathrm{T} 2 \mathrm{D}$, a rare disease of the past became a modern day pandemic. Hence, discovery of novel therapeutic interventions with the potential to rejuvenate beta-cell function and mass will be very crucial in bringing a modern day pandemic disease down to its original rare status.

\section{Declaration of interest}

The authors declare that there is no conflict of interest that could be perceived as prejudicing the impartiality of the research reported. 


\section{Funding}

This study is supported by grants from Akdeniz University Scientific Research Administration Division and the Scientific and Technological Research Council of Turkey (TUBITAK-111S157).

\section{References}

Ahren B 1991 Effects of helospectin I on insulin and glucagon secretion in the mouse. British Journal of Pharmacology 102 916-918. (doi:10.1111/j.1476-5381.1991.tb12276.x)

Ahren B 2000 Autonomic regulation of islet hormone secretion implications for health and disease. Diabetologia 43 393-410. (doi:10.1007/s001250051322)

Ahren B 2008 Role of pituitary adenylate cyclase-activating polypeptide in the pancreatic endocrine system. Annals of the New York Academy of Sciences 1144 28-35. (doi:10.1196/annals.1418.003)

Ahren B 2009 Islet G protein-coupled receptors as potential targets for treatment of type 2 diabetes. Nature Reviews. Drug Discovery 8 369-385. (doi:10.1038/nrd2782)

Ahren B \& Holst JJ 2001 The cephalic insulin response to meal ingestion in humans is dependent on both cholinergic and noncholinergic mechanisms and is important for postprandial glycemia. Diabetes 50 1030-1038. (doi:10.2337/diabetes.50.5.1030)

Ahren B, Holst JJ \& Mari A 2003 Characterization of GLP-1 effects on beta-cell function after meal ingestion in humans. Diabetes Care 26 2860-2864. (doi:10.2337/diacare.26.10.2860)

Ahren B \& Pacini G 2005 Islet adaptation to insulin resistance: mechanisms and implications for intervention. Diabetes, Obesity and Metabolism 7 2-8. (doi:10.1111/j.1463-1326.2004.00361.x)

Aroda VR, Henry RR, Han J, Huang W, Deyoung MB, Darsow T \& Hoogwerf BJ 2012 Efficacy of GLP-1 receptor agonists and DPP-4 inhibitors: meta-analysis and systematic review. Clinical Therapeutics 34 1247-1258. (doi:10.1016/j.clinthera.2012.04.013)

Asnicar MA, Koster A, Heiman ML, Tinsley F, Smith DP, Galbreath E, Fox N, Ma YL, Blum WF \& Hsiung HM 2002 Vasoactive intestinal polypeptide/pituitary adenylate cyclase-activating peptide receptor 2 deficiency in mice results in growth retardation and increased basal metabolic rate. Endocrinology 143 3994-4006. (doi:10.1210/en. 2002-220354)

Bertrand G, Puech R, Maisonnasse Y, Bockaert J \& Loubatieres-Mariani MM 1996 Comparative effects of PACAP and VIP on pancreatic endocrine secretions and vascular resistance in rat. British Journal of Pharmacology 117 764-770. (doi:10.1111/j.1476-5381.1996.tb15256.x)

Bisgin A, Terzioglu E, Aydin C, Yoldas B, Yazisiz V, Balci N, Bagci H, Gorczynski RM, Akdis CA \& Sanlioglu S 2010 TRAIL death receptor4 , decoy receptor- 1 and decoy receptor-2 expression on CD8+ $\mathrm{T}$ cells correlate with the disease severity in patients with rheumatoid arthritis. BMC Musculoskeletal Disorders 11192. (doi:10.1186/1471-2474-11-192)

Borboni P, Porzio O, Pierucci D, Cicconi S, Magnaterra R, Federici M, Sesti G, Lauro D, D'Agata V, Cavallaro S et al. 1999 Molecular and functional characterization of pituitary adenylate cyclase-activating polypeptide (PACAP-38)/vasoactive intestinal polypeptide receptors in pancreatic beta-cells and effects of PACAP-38 on components of the insulin secretory system. Endocrinology 140 5530-5537. (doi:10.1210/en.140.12.5530)

Butler AE, Janson J, Bonner-Weir S, Ritzel R, Rizza RA \& Butler PC 2003 Beta-cell deficit and increased beta-cell apoptosis in humans with type 2 diabetes. Diabetes 52 102-110. (doi:10.2337/diabetes.52.1.102)

Colwell CS, Michel S, Itri J, Rodriguez W, Tam J, Lelievre V, Hu Z, Liu X \& Waschek JA 2003 Disrupted circadian rhythms in VIP- and PHI-deficient mice. American Journal of Physiology. Regulatory, Integrative and Comparative Physiology 285 R939-R949. (doi:10.1152/ ajpregu.00200.2003)
Dejager S \& Schweizer A 2012 Incretin therapies in the management of patients with type 2 diabetes mellitus and renal impairment. Hospital Practice 40 7-21. (doi:10.3810/hp.2012.04.965)

Delgado M, Toscano MG, Benabdellah K, Cobo M, O’Valle F, Gonzalez-Rey E \& Martin F 2008 In vivo delivery of lentiviral vectors expressing vasoactive intestinal peptide complementary DNA as gene therapy for collagen-induced arthritis. Arthritis and Rheumatism 58 1026-1037. (doi:10.1002/art.23283)

Dirice E, Sanlioglu AD, Kahraman S, Ozturk S, Balci MK, Omer A, Griffith TS \& Sanlioglu S 2009 Adenovirus-mediated TRAIL gene (Ad5hTRAIL) delivery into pancreatic islets prolongs normoglycemia in streptozotocin-induced diabetic rats. Human Gene Therapy 20 1177-1189. (doi:10.1089/hum.2009.039)

Dirice E, Kahraman S, Elpek GO, Aydin C, Balci MK, Omer A, Sanlioglu S \& Sanlioglu AD 2011 TRAIL and DcR1 expressions are differentially regulated in the pancreatic islets of STZ- versus CY-applied NOD mice. Experimental Diabetes Research 2011625813. (doi:10.1155/2011/625813)

Doerschug K, Sanlioglu S, Flaherty DM, Wilson RL, Yarovinsky T, Monick MM, Engelhardt JF \& Hunninghake GW 2002 Firstgeneration adenovirus vectors shorten survival time in a murine model of sepsis. Journal of Immunology 169 6539-6545.

Eliasson L, Ma X, Renström E, Barg S, Berggren PO, Galvanovskis J, Gromada J, Jing X, Lundquist I, Salehi A et al. 2003 SUR1 regulates PKA-independent cAMP-induced granule priming in mouse pancreatic B-cells. Journal of General Physiology 121 181-197. (doi:10.1085/jgp.20028707)

Elsner M, Terbish T, Jorns A, Naujok O, Wedekind D, Hedrich HJ \& Lenzen S 2012 Reversal of diabetes through gene therapy of diabetic rats by hepatic insulin expression via lentiviral transduction. Molecular Therapy 20 918-926. (doi:10.1038/mt.2012.8)

Fabricius D, Karacay B, Shutt D, Leverich W, Schafer B, Takle E, Thedens D, Khanna G, Raikwar S, Yang B et al. 2011 Characterization of intestinal and pancreatic dysfunction in VPAC1-null mutant mouse. Pancreas 40 861-871. (doi:10.1097/MPA. 0b013e318214c783)

Filipsson K, Sundler F \& Ahren B 1999 PACAP is an islet neuropeptide which contributes to glucose-stimulated insulin secretion. Biochemical and Biophysical Research Communications 256 664-667. (doi:10.1006/bbrc.1999.0395)

Gonzalez-Rey E, Chorny A, Fernandez-Martin A, Ganea D \& Delgado M 2006 Vasoactive intestinal peptide generates human tolerogenic dendritic cells that induce CD4 and CD8 regulatory Tcells. Blood 107 3632-3638. (doi:10.1182/blood-2005-11-4497)

Green BD, Irwin N, Cassidy RS, Gault VA \& Flatt PR 2006 Long-term administration of PACAP receptor antagonist, PACAP(6-27), impairs glucose tolerance and insulin sensitivity in obese diabetic ob/ob mice. Peptides 27 2343-2349. (doi:10.1016/j.peptides.2006.04.008)

Hannibal J \& Fahrenkrug J 2000 Pituitary adenylate cyclase-activating polypeptide in intrinsic and extrinsic nerves of the rat pancreas. Cell and Tissue Research 299 59-70. (doi:10.1007/s004410050006)

Harmar AJ, Fahrenkrug J, Gozes I, Laburthe M, May V, Pisegna JR, Vaudry D, Vaudry H, Waschek JA \& Said SI 2012 Pharmacology and functions of receptors for vasoactive intestinal peptide and pituitary adenylate cyclase-activating polypeptide: IUPHAR review 1 . British Journal of Pharmacology 166 4-17. (doi:10.1111/j.1476-5381.2012. 01871.x)

Hashimoto H, Shintani N, Tanaka K, Mori W, Hirose M, Matsuda T, Sakaue M, Miyazaki J, Niwa H, Tashiro F et al. 2001 Altered psychomotor behaviors in mice lacking pituitary adenylate cyclase-activating polypeptide (PACAP). PNAS 98 13355-13360. (doi:10.1073/pnas.231094498)

Havel PJ, Dunning BE, Verchere CB, Baskin DG, O'Dorisio T \& Taborsky GJJ 1997 Evidence that vasoactive intestinal polypeptide is a parasympathetic neurotransmitter in the endocrine pancreas in dogs. Regulatory Peptides 71 163-170. (doi:10.1016/S0167-0115(97) 01014-8) 
Henquin JC 2000 Triggering and amplifying pathways of regulation of insulin secretion by glucose. Diabetes 49 1751-1760. (doi:10.2337) diabetes.49.11.1751)

Henquin JC 2009 Regulation of insulin secretion: a matter of phase control and amplitude modulation. Diabetologia 52 739-751. (doi:10.1007/s00125-009-1314-y)

Herrera JL, Fernandez-Montesinos R, Gonzalez-Rey E, Delgado M \& Pozo D 2006 Protective role for plasmid DNA-mediated VIP gene transfer in non-obese diabetic mice. Annals of the New York Academy of Sciences 1070 337-341. (doi:10.1196/annals.1317.041)

Hultgardh-Nilsson A, Nilsson J, Jonzon B \& Dalsgaard CJ 1988 Growthinhibitory properties of vasoactive intestinal polypeptide. Regulatory Peptides 22 267-274. (doi:10.1016/0167-0115(88)90039-0)

Inagaki N, Yoshida H, Mizuta M, Mizuno N, Fujii Y, Gonoi T, Miyazaki J \& Seino S 1994 Cloning and functional characterization of a third pituitary adenylate cyclase-activating polypeptide receptor subtype expressed in insulin-secreting cells. PNAS 91 2679-2683. (doi:10.1073/pnas.91.7.2679)

Jamen F, Persson K, Bertrand G, Rodriguez-Henche N, Puech R, Bockaert J, Ahren B \& Brabet P 2000 PAC1 receptor-deficient mice display impaired insulinotropic response to glucose and reduced glucose tolerance. Journal of Clinical Investigation 105 1307-1315. (doi:10.1172/JCI9387)

Jamen F, Puech R, Bockaert J, Brabet P \& Bertrand G 2002 Pituitary adenylate cyclase-activating polypeptide receptors mediating insulin secretion in rodent pancreatic islets are coupled to adenylate cyclase but not to PLC. Endocrinology 143 1253-1259. (doi:10.1210/en.143.4.1253)

Kato I, Suzuki Y, Akabane A, Yonekura H, Tanaka O, Kondo H, Takasawa S, Yoshimoto T \& Okamoto H 1994 Transgenic mice overexpressing human vasoactive intestinal peptide (VIP) gene in pancreatic beta cells. Evidence for improved glucose tolerance and enhanced insulin secretion by VIP and PHM-27 in vivo. Journal of Biological Chemistry 269 21223-21228.

Kato I, Suzuki Y, Akabane A, Yonekura H, Tanaka O, Kondo H, Takasawa S, Yoshimoto T \& Okamoto H 1996 Enhancement of glucose-induced insulin secretion in transgenic mice overexpressing human VIP gene in pancreatic beta cells. Annals of the New York Academy of Sciences 805 232-242 (discussion 242-243). (doi:10.1111/ j.1749-6632.1996.tb17486.x)

Knop FK, Vilsboll T \& Holst JJ 2009 Incretin-based therapy of type 2 diabetes mellitus. Current Protein and Peptide Science 10 46-55. (doi:10.2174/138920309787315158)

Kok MR, Baum BJ, Tak PP \& Pillemer SR 2003 Use of localised gene transfer to develop new treatment strategies for the salivary component of Sjogren's syndrome. Annals of the Rheumatic Diseases 62 1038-1046. (doi:10.1136/ard.62.11.1038)

Kulkarni RN, Smith DM, Ghatei MA \& Bloom SR 1995 A 67 kDa protein mediates pituitary adenylate cyclase-activating polypeptide and vasoactive intestinal peptide-stimulated insulin secretion in a hamster clonal beta-cell line. Journal of Endocrinology 147 121-130. (doi:10.1677/joe.0.1470121)

Lambeir AM, Durinx C, Proost P, Van Damme J, Scharpe S \& De Meester I 2001 Kinetic study of the processing by dipeptidylpeptidase IV/CD26 of neuropeptides involved in pancreatic insulin secretion. FEBS Letters 507 327-330. (doi:10.1016/S0014-5793(01) 02982-9)

Leibowitz G, Kaiser N \& Cerasi E 2011 Beta cell failure in type 2 diabetes. Journal of Diabetes Investigation 2 82-91. (doi:10.1111/ j.2040-1124.2010.00094.x)

Liu YJ, Guo YF, Zhang LS, Pei YF, Yu N, Yu P, Papasian CJ \& Deng HW 2010 Biological pathway-based genome-wide association analysis identified the vasoactive intestinal peptide (VIP) pathway important for obesity. Obesity 18 2339-2346. (doi:10.1038/oby.2010.83)

Lodde BM, Delporte C, Goldsmith CM, Tak PP \& Baum BJ 2004 A recombinant adenoviral vector encoding functional vasoactive intestinal peptide. Biochemical and Biophysical Research Communications 319 189-192. (doi:10.1016/j.bbrc.2004.04.171)
Lodde BM, Mineshiba F, Wang J, Cotrim AP, Afione S, Tak PP \& Baum BJ 2006 Effect of human vasoactive intestinal peptide gene transfer in a murine model of Sjogren's syndrome. Annals of the Rheumatic Diseases 65 195-200. (doi:10.1136/ard.2005.038232)

Lu N, Zhou R \& DiCicco-Bloom E 1998 Opposing mitogenic regulation by PACAP in sympathetic and cerebral cortical precursors correlates with differential expression of PACAP receptor (PAC1-R) isoforms. Journal of Neuroscience Research $\mathbf{5 3}$ 651-662. (doi:10.1002/(SICI) 1097-4547(19980915)53:6<651:: AID-JNR3 > 3.0.CO;2-4)

Martin B, Shin YK, White CM, Ji S, Kim W, Carlson OD, Napora JK, Chadwick W, Chapter M, Waschek JA et al. 2010 Vasoactive intestinal peptide-null mice demonstrate enhanced sweet taste preference, dysglycemia, and reduced taste bud leptin receptor expression. Diabetes 59 1143-1152. (doi:10.2337/db09-0807)

Maruno K, Absood A \& Said SI 1995 VIP inhibits basal and histaminestimulated proliferation of human airway smooth muscle cells. American Journal of Physiology 268 L1047-L1051.

Mentlein R 1999 Dipeptidyl-peptidase IV (CD26) - role in the inactivation of regulatory peptides. Regulatory Peptides 85 9-24. (doi:10.1016/S0167-0115(99)00089-0)

Meyer DK 2006 The effects of PACAP on neural cell proliferation. Regulatory Peptides 137 50-57. (doi:10.1016/j.regpep.2006.03.009)

Moody TW, Ito T, Osefo N \& Jensen RT 2011 VIP and PACAP: recent insights into their functions/roles in physiology and disease from molecular and genetic studies. Current Opinion in Endocrinology, Diabetes, and Obesity 18 61-67. (doi:10.1097/MED. 0b013e328342568a)

Nakata M, Shintani N, Hashimoto H, Baba A \& Yada T 2010 Intra-islet PACAP protects pancreatic beta-cells against glucotoxicity and lipotoxicity. Journal of Molecular Neuroscience 42 404-410. (doi:10.1007/s12031-010-9383-4)

Niswender K 2010 Diabetes and obesity: therapeutic targeting and risk reduction - a complex interplay. Diabetes, Obesity and Metabolism 12 267-287. (doi:10.1111/j.1463-1326.2009.01175.x)

Pan CQ, Li F, Tom I, Wang W, Dumas M, Froland W, Yung SL, Li Y, Roczniak S, Claus TH et al. 2007 Engineering novel VPAC2-selective agonists with improved stability and glucose-lowering activity in vivo. Journal of Pharmacology and Experimental Therapeutics 320 900-906. (doi:10.1124/jpet.106.112276)

Persson K \& Ahren B 2002 The neuropeptide PACAP contributes to the glucagon response to insulin-induced hypoglycaemia in mice. Acta Physiologica Scandinavica 175 25-28. (doi:10.1046/j.1365-201X. 2002.00977.x)

Persson-Sjogren S, Forsgren S \& Lindstrom P 2006 Vasoactive intestinal polypeptide and pituitary adenylate cyclase activating polypeptide: effects on insulin release in isolated mouse islets in relation to metabolic status and age. Neuropeptides 40 283-290. (doi:10.1016/j.npep.2006.04.001)

Peters A 2010 Incretin-based therapies: review of current clinical trial data. American Journal of Medicine 123 S28-S37. (doi:10.1016/ j.amjmed.2009.12.007)

Peterson G 2012 Current treatments and strategies for type 2 diabetes: can we do better with GLP-1 receptor agonists? Annals of Medicine 44 338-349. (doi:10.3109/07853890.2011.653392)

Petkov V, Mosgoeller W, Ziesche R, Raderer M, Stiebellehner L, Vonbank K, Funk G, Hamilton G, Novotny C, Burian B et al. 2003 Vasoactive intestinal peptide as a new drug for treatment of primary pulmonary hypertension. Journal of Clinical Investigation 111 1339-1346. (doi:10.1172/JCI200317500)

Reaven GM, Chen YD, Golay A, Swislocki AL \& Jaspan JB 1987 Documentation of hyperglucagonemia throughout the day in nonobese and obese patients with noninsulin-dependent diabetes mellitus. Journal of Clinical Endocrinology and Metabolism 64 106-110. (doi:10.1210/jcem-64-1-106)

Robberecht P, Gourlet P, De Neef P, Woussen-Colle MC, Vandermeers-Piret MC, Vandermeers A \& Christophe J 1992 Structural requirements for the occupancy of pituitary 
adenylate-cyclase-activating-peptide (PACAP) receptors and adenylate cyclase activation in human neuroblastoma NB-OK-1 cell membranes. Discovery of PACAP(6-38) as a potent antagonist. European Journal of Biochemistry 207 239-246. (doi:10.1111/j.14321033.1992.tb17043.x)

Rosignoli F, Torroba M, Juarranz Y, Garcia-Gomez M, Martinez C, Gomariz RP, Perez-Leiros C \& Leceta J 2006 VIP and tolerance induction in autoimmunity. Annals of the New York Academy of Sciences 1070 525-530. (doi:10.1196/annals.1317.073)

Said SI, Hamidi SA, Dickman KG, Szema AM, Lyubsky S, Lin RZ, Jiang YP, Chen JJ, Waschek JA \& Kort S 2007 Moderate pulmonary arterial hypertension in male mice lacking the vasoactive intestinal peptide gene. Circulation 115 1260-1268. (doi:10.1161/CIRCULATIONAHA.106.681718)

Sakurai Y, Shintani N, Hayata A, Hashimoto H \& Baba A 2011 Trophic effects of PACAP on pancreatic islets: a mini-review. Journal of Molecular Neuroscience 43 3-7. (doi:10.1007/s12031-010-9424-z)

Sanlioglu S, Monick MM, Luleci G, Hunninghake GW \& Engelhardt JF 2001 Rate limiting steps of AAV transduction and implications for human gene therapy. Current Gene Therapy 1 137-147. (doi:10.2174/ 1566523013348788)

Sanlioglu AD, Dirice E, Elpek O, Korcum AF, Balci MK, Omer A, Griffith TS \& Sanlioglu S 2008a High levels of endogenous tumor necrosis factor-related apoptosis-inducing ligand expression correlate with increased cell death in human pancreas. Pancreas $\mathbf{3 6}$ 385-393. (doi:10.1097/MPA.0b013e318158a4e5)

Sanlioglu AD, Griffith TS, Omer A, Dirice E, Sari R, Altunbas HA, Balci MK \& Sanlioglu S 2008b Molecular mechanisms of death ligand-mediated immune modulation: a gene therapy model to prolong islet survival in type 1 diabetes. Journal of Cellular Biochemistry 104 710-720. (doi:10.1002/jcb.21677)

Sanlioglu AD, Altunbas HA, Balci MK, Griffith TS \& Sanlioglu S 2012 Insulin gene therapy from design to beta cell generation. Expert Reviews in Molecular Medicine. In press. (doi:10.1017/erm.2012.12)

Sherwood NM, Krueckl SL \& McRory JE 2000 The origin and function of the pituitary adenylate cyclase-activating polypeptide (PACAP)/ glucagon superfamily. Endocrine Reviews 21 619-670. (doi:10.1210/ er.21.6.619)

Shintani N, Tomimoto S, Hashimoto H, Kawaguchi C \& Baba A 2003 Functional roles of the neuropeptide PACAP in brain and pancreas. Life Sciences 74 337-343. (doi:10.1016/j.lfs.2003.09.021)

Shioda S, Ohtaki H, Nakamachi T, Dohi K, Watanabe J, Nakajo S, Arata S, Kitamura S, Okuda H, Takenoya F et al. 2006 Pleiotropic functions of PACAP in the CNS: neuroprotection and neurodevelopment. Annals of the New York Academy of Sciences $\mathbf{1 0 7 0}$ 550-560. (doi:10.1196/annals.1317.080)

Sloop KW, Michael MD \& Moyers JS 2005 Glucagon as a target for the treatment of type 2 diabetes. Expert Opinion on Therapeutic Targets 9 593-600. (doi:10.1517/14728222.9.3.593)

Spengler D, Waeber C, Pantaloni C, Holsboer F, Bockaert J, Seeburg PH \& Journot L 1993 Differential signal transduction by five splice variants of the PACAP receptor. Nature 365 170-175. (doi:10.1038/365170a0)

Srinivasan K, Viswanad B, Asrat L, Kaul CL \& Ramarao P 2005 Combination of high-fat diet-fed and low-dose streptozotocintreated rat: a model for type 2 diabetes and pharmacological screening. Pharmacological Research 52 313-320. (doi:10.1016/j.phrs. 2005.05.004)

St Hilaire RC, Kadowitz PJ \& Jeter JRJ 2009 Adenoviral transfer of vasoactive intestinal peptide (VIP) gene inhibits rat aortic and pulmonary artery smooth muscle cell proliferation. Peptides $\mathbf{3 0}$ 2323-2329. (doi:10.1016/j.peptides.2009.08.010)

Stolerman ES \& Florez JC 2009 Genomics of type 2 diabetes mellitus: implications for the clinician. Nature Reviews. Endocrinology 5 429-436. (doi:10.1038/nrendo.2009.129)

Tabak AG, Herder C, Rathmann W, Brunner EJ \& Kivimaki M 2012 Prediabetes: a high-risk state for diabetes development. Lancet $\mathbf{3 7 9}$ 2279-2290. (doi:10.1016/S0140-6736(12)60283-9)
Terzioglu E, Bisgin A, Sanlioglu AD, Ulker M, Yazisiz V, Tuzuner S \& Sanlioglu S 2007 Concurrent gene therapy strategies effectively destroy synoviocytes of patients with rheumatoid arthritis. Rheumatology 46 783-789. (doi:10.1093/rheumatology/kel448)

Tsutsumi M, Claus TH, Liang Y, Li Y, Yang L, Zhu J, Dela Cruz F, Peng X, Chen H, Yung SL et al. 2002 A potent and highly selective VPAC2 agonist enhances glucose-induced insulin release and glucose disposal: a potential therapy for type 2 diabetes. Diabetes 51 1453-1460. (doi:10.2337/diabetes.51.5.1453)

Vaudry D, Falluel-Morel A, Bourgault S, Basille M, Burel D, Wurtz O, Fournier A, Chow BK, Hashimoto H, Galas L et al. 2009 Pituitary adenylate cyclase-activating polypeptide and its receptors: 20 years after the discovery. Pharmacological Reviews 61 283-357. (doi:10.1124/pr.109.001370)

Vilsboll T 2009 The effects of glucagon-like peptide-1 on the beta cell. Diabetes, Obesity and Metabolism 11 (Suppl 3) 11-18. (doi:10.1111/ j.1463-1326.2009.01073.x)

Vilsboll T \& Holst JJ 2004 Incretins, insulin secretion and Type 2 diabetes mellitus. Diabetologia 47 357-366. (doi:10.1007/s00125-0041342-6)

Vilsboll T, Christensen M, Junker AE, Knop FK \& Gluud LL 2012 Effects of glucagon-like peptide-1 receptor agonists on weight loss: systematic review and meta-analyses of randomised controlled trials. BMJ 344 d7771. (doi:10.1136/bmj.d7771)

Winzell MS \& Ahren B 2004 The high-fat diet-fed mouse: a model for studying mechanisms and treatment of impaired glucose tolerance and type 2 diabetes. Diabetes 53 (Suppl 3) S215-S219. (doi:10.2337/ diabetes.53.suppl_3.S215)

Winzell MS, Brand CL, Wierup N, Sidelmann UG, Sundler F, Nishimura E \& Ahren B 2007 Glucagon receptor antagonism improves islet function in mice with insulin resistance induced by a high-fat diet. Diabetologia 50 1453-1462. (doi:10.1007/ s00125-007-0675-3)

Yada T, Sakurada M, Ishihara H, Nakata M, Shioda S, Yaekura K, Hamakawa N, Yanagida K, Kikuchi M \& Oka Y 1997 Pituitary adenylate cyclase-activating polypeptide (PACAP) is an islet substance serving as an intra-islet amplifier of glucose-induced insulin secretion in rats. Journal of Physiology 505 319-328. (doi:10.1111/j.1469-7793.1997.319bb.x)

Yada T, Sakurada M, Filipsson K, Kikuchi M \& Ahren B 2000 Intraperitoneal PACAP administration decreases blood glucose in GK rats, and in normal and high fat diet mice. Annals of the New York Academy of Sciences 921 259-263. (doi:10.1111/j.1749-6632.2000. tb06974.x)

Yamamoto K, Hashimoto H, Tomimoto S, Shintani N, Miyazaki J, Tashiro F, Aihara H, Nammo T, Li M, Yamagata K et al. 2003 Overexpression of PACAP in transgenic mouse pancreatic betacells enhances insulin secretion and ameliorates streptozotocininduced diabetes. Diabetes 52 1155-1162. (doi:10.2337/diabetes.52. 5.1155)

Yokota C, Kawai K, Ohashi S, Watanabe Y \& Yamashita K 1995 PACAP stimulates glucose output from the perfused rat liver. Peptides 16 55-60. (doi:10.1016/0196-9781(94)00143-T)

Zhu L, Tamvakopoulos C, Xie D, Dragovic J, Shen X, Fenyk-Melody JE, Schmidt K, Bagchi A, Griffin PR, Thornberry NA et al. 2003 The role of dipeptidyl peptidase IV in the cleavage of glucagon family peptides: in vivo metabolism of pituitary adenylate cyclase activating polypeptide-(1-38). Journal of Biological Chemistry 278 22418-22423. (doi:10.1074/jbc.M212355200)

Received in final form 10 September 2012 Accepted 18 September 2012 Made available online as an Accepted Preprint 18 September 2012 